Journal of Engineering and Applied Sciences 15 (2): 492-500, 2020

ISSN: 1816-949X

(C) Medwell Journals, 2020

\title{
Analysis of Regional Defense Threat for Non-Military Aspect at Bandung Municipality using Root Cause Analysis (RCA) and Analytical Hierarchy Process (AHP) Approach
}

\author{
Wibisono Poespitohadi, Soesilo Zuhar, B.S. Haryono, Fadillah Amin, \\ Zaenal Fanani and Romy Hermawa \\ Brawijaya University, Veteran Malang, Ketawanggede, Lowokwaru Malang, \\ 65145 Jawa Timur, Indonesia
}

\begin{abstract}
Threats to the state are every effort and activity, both domestic and foreign which are considered to endanger the sovereignty of the country, the territorial integrity of the country and the safety of all nations. The threats certainly affect national stability including those occurring in some of the capital's buffer zones, namely Bandung Municipality. The Bandung Municipality has a number of non-military threats. This study aims at providing an analysis of non-military threats in the Bandung Municipality. This study uses Root Cause Analysis (RCA) and Analytical Hierarchy Process (AHP) method approach. Root cause analysis uses to identified a criteria for non-military threat. AHP method is used to give the weight and priority to criteria and sub-criteria. The form of non-military threats is: dimensional threats of ideology, political dimension threats, economic dimension threats, socio-cultural dimensions, threats of dimension of technology and information, dimensional threads of public safety and threat dimension of legal legality. The results of weighting the threat criteria are known that the Ideological criterion (I) has a weight of 0.115; Political aspect (P) has a weight of 0.162 ; Economic aspect (E) has a weight of 0.074; Socio-Cultural aspects (SC) have a weight of 0.109; Public Safety aspect (PS) has a weight of 0.224; Technological aspect (T) has a weight of 0.133; Legality (L) has a weight of 0.183 . At level $\mathrm{I}$, the highest threat aspect is the public safety aspect with a weight of 0.224 . While the lowest threat aspect is the economic aspect with a weight of 0.074 . Otherwise, at level II, the highest one is the overlapping of rules from the regional government with a weight of 0.099 . While the lowest threat is poverty with a weight of 0.006 .
\end{abstract}

Key words: Non-military threats, bandung municipality, Root Cause Analysis (RCA), Analytical Hierarchy Process (AHP), economic aspec, public safety

\section{INTRODUCTION}

Threats to the state are every effort and activity, both domestic and foreign which are considered to endanger the sovereignty of the country, the territorial integrity of the country and the safety of all nations (Jones et al., 2009). The development of strategic issues has broadened the perspective in viewing at the complexity of the threats that exists and influencing the development of security conceptions. The threat is not only about a military threat but also includes political, social, economic and ecological threats (Van Der Putten et al., 2015).

The threats certainly affect national stability including those occurring in some of the capital's buffer zones, namely Bandung Municipality. The Bandung Municipality has a number of non-military threats. In one hand, the threats are not much identified. This study aims at providing an analysis of non-military threats in the Bandung Municipality. This study is expected to contribute to stakeholders in determining policies to overcome non-military threats in the Bandung Municipality.

This study uses Root Cause Analysis (RCA) and Analytical Hierarchy Process (AHP) method approach. Root cause analysis uses to identify criteria for non-military threat. AHP method is used to give the weight and priority to criteria and sub-criteria. AHP method is developed by Saaty and is used to solve complex problems in which data and statistical information from the problems faced are very few (Karakayaci, 2015) Analytical Hierarchy Process (AHP) is a form of decision-making model with multiple criteria (Hou et al., 2015). One of AHP's reliability is able to simultaneously carry out the analysis between qualitative or even quantitative parameters (Ho et al., 2016).

There are some previous studies supporting this research, RCA is used to identify the real causes of problems, defects or failures observed so that they can be

Corresponding Author: Wibisono Poespitohadi, Brawijaya University, Veteran Malang, Ketawanggede, Lowokwaru Malang, 65145 Jawa Timur, Indonesia 
used to improve the situation (Menon et al., 2016). The RCA is used to provide analysis of defects in the production process and modified according to the results of the analysis (Gosavi and Inamdar, 2014). The RCA is used to identify and analyze various risk factors, risk classification, risk quantification and problems in construction companies (Ramkumar and Gopalakrishnan, 2014). The RCA is used to define the analysis of the main causes and apply the reverse index of the method to business transactions performance problems (Zhou and $\mathrm{Li}, 2015$ ).

The AHP as a model for consumer decision-making in a digital market (Singh et al., 2016). The AHP as a measure of performance indicators on the companies based on four aspects of the BSC (Maharma and Saleh, 2014). The AHP to provide the essence aspect and sustainable criteria in the industry (Kalutara et al., 2018). The AHP as a framework to select the procurement of building maintenance (Chua et al., 2015). The AHP aims at assessing and dealing with related problems at the Higher Learning Institution (HLI) (Anis and Islam, 2015). The AHP is for designing a system to evaluate the performance of human resources (Mutmainah et al., 2017). The AHP to determine the strategy of cafe menu selection (Hou et al., 2015). The AHP is to identify critical success factors in the management of veteran personnel (Chien and Barthorpe, 2013).

\section{MATERIALS AND METHODS}

Non-military state defense system: The national defense system in facing of non-military threats locates government in the institutions outside the defense sector as the main element in accordance with the form and characteristic of the threats faced with the support of other elements of the nation's strength (Mastapeter, 2008). The main strengths in overcoming the non-military threats are the main elements as well as a guarantee of the synergy between military and non-military defenses in the implementation of national defense (The Ministry of Defence, 2015).

Non-military threats are essentially, a threat by using factors considered to have the ability to endanger the sovereignty of the state, the integrity of the territory of the state and the safety of all nations (Grozdanoska, 2014). The form of non-military threats is (Jouini et al., 2015). Dimensional threats of ideology, political dimension threats, economic dimension threats, socio-cultural dimensions, threats of dimension of technology and information, dimensional threads of public safety and threat dimension of legal legality.

Bandung Municipality: Bandung Municipality is located in a region of West Java and constitutes Capital of West Java. Astronomically, it is located between 1070 36' East longitudes and 06055 ' South latitudes. In terms of geographic position, Bandung Municipality has boundaries as follows: North-Bandung Regency and West Bandung Regency; South-Bandung Regency; West-Cimahi Municipality; East-Bandung Regency (Chaerul et al., 2007).

Bandung is located at an altitude of 700 masl (meters above sea level). The highest point in Ledeng, Cidadap district with a height of 892 masl and the lowest in Rancanumpang, Gedebage district with an altitude of 666 masl. The total area of Bandung Municipality is $167.31 \mathrm{~km}^{2}$. It is divided into 30 districts covering 151 subdistricts. Gedebage district is the widest district with $9.58 \mathrm{~km}^{2}$ area. Astananyar is the district with the smallest area, that is $2.89 \mathrm{~km}^{2}$ (Indrayani, 2018).

The government structure of Bandung Municipality is led by mayor, vice mayor and assisted by local instruments. The instrument of Bandung Municipality consists the Bandung Municipality secretariat, regional agency, regional offices, the regional inspectorate, sub-district office, urban village office, regional companies and regionally owned enterprises (Aldianto et al., 2019) (Fig. 1).

Bandung Municipality has 30 districts Bandung Municipality has 150 subdistricts Bandung population-based population projections for 2017 were 2.497.938 people consisting of 1.260.204 inhabitants of the male and 1.237.734 female population people. When it is compared with the number in previous year, it has increased $0.29 \%$. The sex ratio in 2017 is 102.04 . Human Development Index (HDI) in Bandung in 2017 was 80.31. This index is described by component life expectancy (AHH) 73,86 years, The expectations of year school is 13.90 years, mean of years school was 10.59 years and per capita spending 16.033 thousand rupiahs (Miftah et al., 2019).

This certainly affects the pattern of change in people's life and threatens their existence. Based on the observed results, there were several non-military threats in Bandung Municipality such as: ideological threats, political threats (trust in government, separatism, living environment, democratization), economical threats, socio-cultural threats, public safety threats, technological threats and legalitical issues.

Root Cause Analysis (RCA): Root Cause Analysis (RCA) is a problem-solving process for investigating a problem, concern or incompatibility of problems found (Gosavi and Inamdar, 2014). The RCA requires investigators to find solutions to urgent problems and understand the fundamental or fundamental causes of a situation and treat the problem appropriately, thus, preventing the re-occurrence of the same problems. Therefore, it may involve identifying and managing processes, procedures, activities, activities, behaviors or conditions (Menon et al., 2016). 


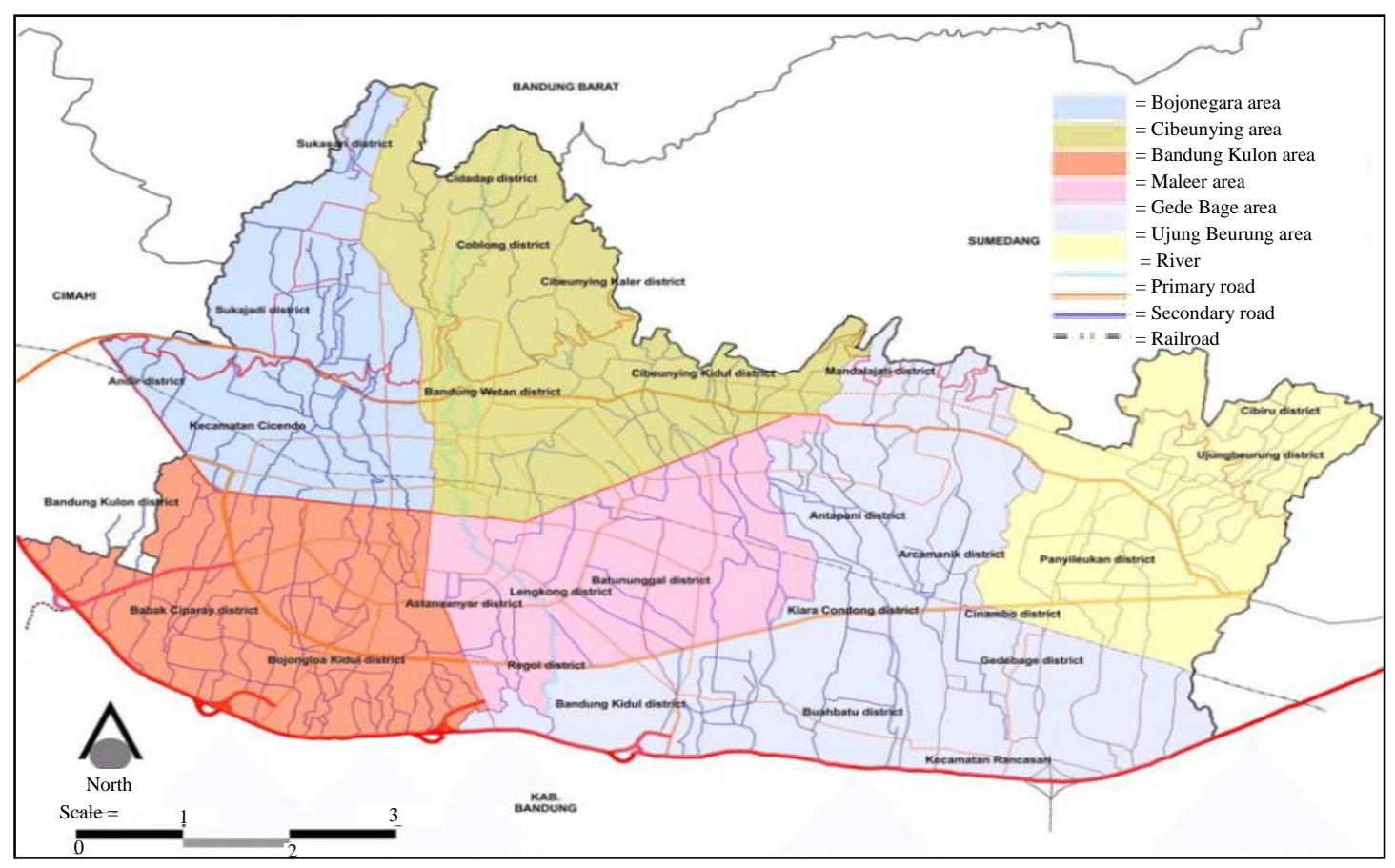

Fig. 1: Map of Bandung Municipality

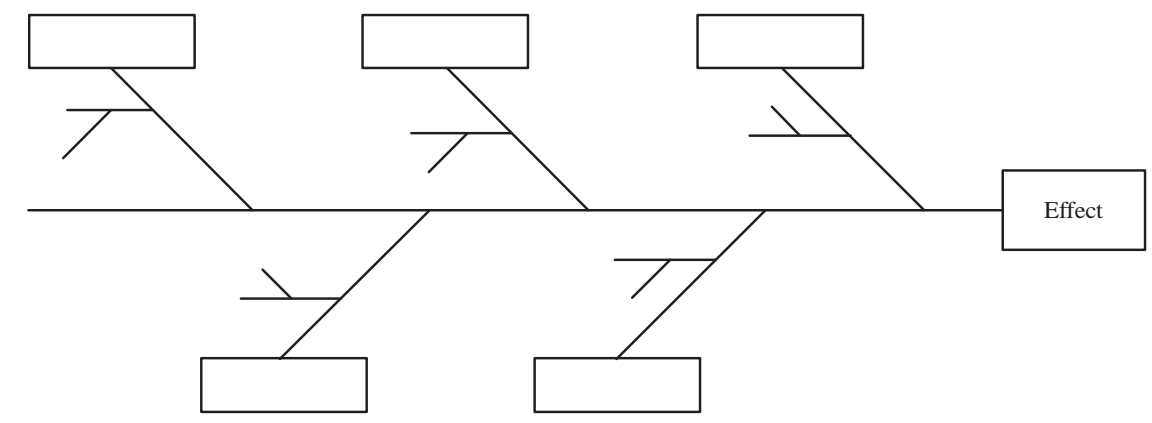

Fig. 2: Fishbone diagram structure (Septiawan and Bekti, 2016)

The steps in Root Cause Analysis (RCA) are as follows: Defining the problem (Define the nonconformity), submit an action plan (create proposed action plan), implement an action plan (implement proposed action), perform monitoring (verification and monitoring of effectiveness) (Ramkumar and Gopalakrishnan, 2014).

There are various structured evaluation methods to identify the root cause of an unexpected event (undesired outcome). There are currently popular methods for identifying root causes from simple to complex ones, namely (Zhou and Li, 2015).

The 5-whys: The 5-whys is the simplest method for structured root cause analysis.This is a method of asking questions that are used to explore the causes of the relationships underlying the problem.
Fishbone diagrams or the Cause and Effect Diagrams (CED): The second method is a fishbone diagram. The purpose of describing a problem in a diagram or image is to make it easier for us to understand the description of the problem and the factors that cause the problem to arise in one diagram or image (Septiawan and Bekti, 2016) (Fig. 2).

Analytical Hierarchy Process (AHP): Basically, AHP is a general theory of measurement used to find the ratio scale from both a comparison of discrete and continuous pairs (Setiarso et al., 2018). These comparisons can be taken from the actual size or from a basic scale that reflects the strength of feelings and relative preferences. The AHP has special attention about deviations from consistency, measurement and dependency within and between groups of structural elements (Dlbokic et al., 2017). 


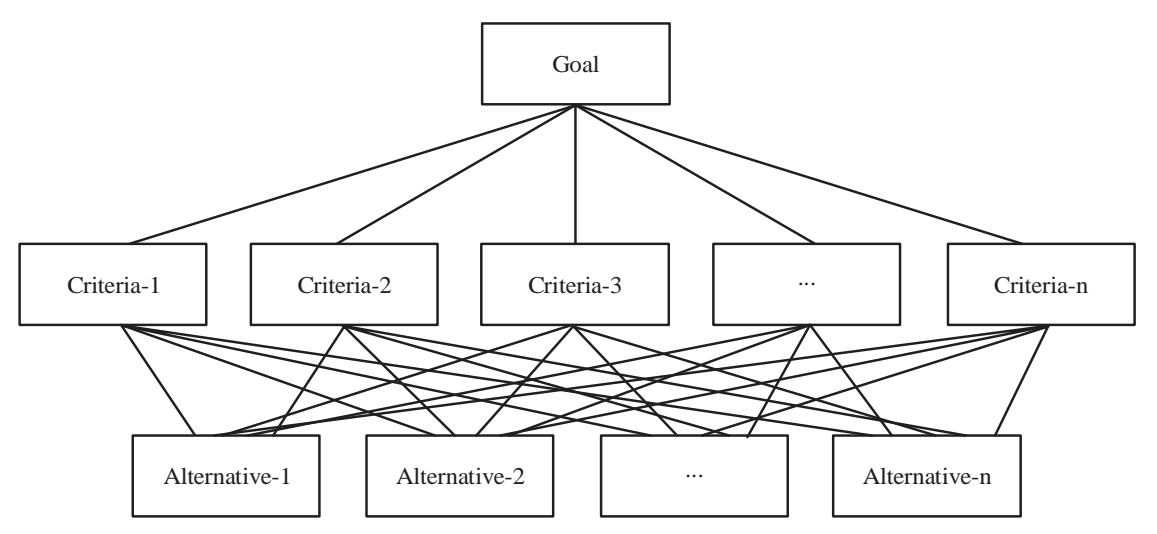

Fig. 3: Model of Analytic Hierarchy Process (AHP) (Wang, 2015)

The steps of the AHP method are as follows (Saaty, 2003) (Fig. 3): (1) define the problem and determining the expected solution. (2) create a hierarchical structure started by a general goal and followed by criteria and alternative choices are expected to rank. (3) form a pairwise comparison matrix that describes the relative contribution or influence of each element to each objective or criteria above. (4) normalize data by dividing the value of each element in the matrix in pairs with the total value of each column. (5) calculate the eigenvector and test its consistency, if it is not consistent then the data retrieval (preference) needs to be repeated. (6) repeat steps 3, 4 and 5 for all levels of the hierarchy. (7) calculate eigenvector from each pairwise comparison matrix. The eigenvector value is the weight of each element. This step is to synthesize the options in prioritizing elements at the lowest hierarchy level until the goal is reached. (8) test the consistency of the hierarchy. The comparison number in a pairwise comparison is a scale of 1-9 where (Saaty and Vargas, 2006):

- $\quad$ Scale 1 = equal between one interest and another

- $\quad$ Scale $3=$ medium category is compared to other interests

- $\quad$ Scale 5 = sufficient category is compared to other interests

- $\quad$ Scale 7 = very strong category is compared to other interests

- $\quad$ Scale $9=$ one interest is extremely stronger than other interests

- Scale 2, 4, 6, 8 = value between two adjacent assessments

\section{RESULTS AND DISCUSSION}

In determining the level of non-military threats from decision elements at each level of the decision hierarchy, opinion assessment is carried out by using the thinking function being combined with feeling and sensing preferences. In this study, identification of criteria in the sub-analysis of non-military threats using the root cause analysis with fishbone diagram approach.

Data retrieval is done through questionnaires with 6 experts. Expert is appointed based on current job capabilities and position. the six experts, among others: Mayor of Bandung, head of city planning and spatial planning, head of planning and budget services, military district commander, expert staff of city government, university lecturers. The results of the identification of criteria from the expert can be seen in Table 1 and Fig. 4.

Assessment can be done by a pairwise comparison, namely by comparing each element with other elements in each criterion (Fig. 4). So, the value of the element interest in the form of qualitative opinions is used as an assessment scale, so that, it will be obtained in the form of numbers. Based on the table and Fig. 4 there are 7 dimensions of criteria. The first, second and third criteria consist of four sub-criteria. The fourth criterion consists of seven sub-criteria. The fifth criterion consists of five sub-criteria. The sixth and seventh criteria consist of three sub-criteria (Fig. 5).

The next discussion is about the breakdown of the research results conducted in order to analyze the essence of non-military threats. The stages of the research are to explain the results of the Analytical Hierarchy Process (AHP) method manually, the analysis and discussion of the result. At this stage, the weighting of each criterion uses the AHP Model. Criteria data are obtained from questionnaires and direct interviews with selected experts to compare criteria.

Based on Table 2, the results of weighting the threat criteria are known that the Ideological criterion (I) has a weight of 0.115 , Political aspect $(\mathrm{P})$ has a weight of 0.162 , Economic aspect (E) has a weight of 0.074, Socio-Cultural aspects (SC) has a weight of 0.109, Public Safety aspect (PS) has a weight of 0.224 , Technological aspect $(\mathrm{T})$ has a weight of 0.133 , Legality (L) has a weight of 0.183 . 


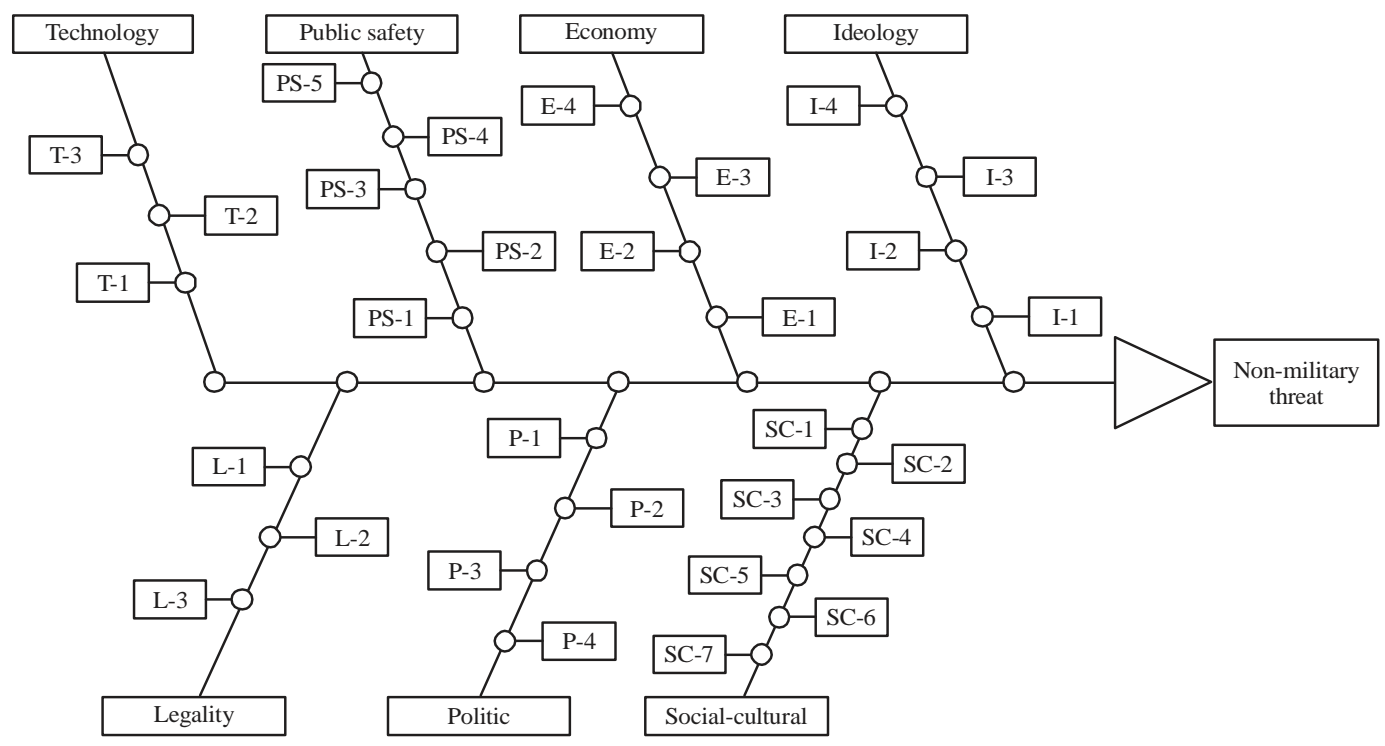

Fig. 4: Fishbone diagram analysis for non-military threat

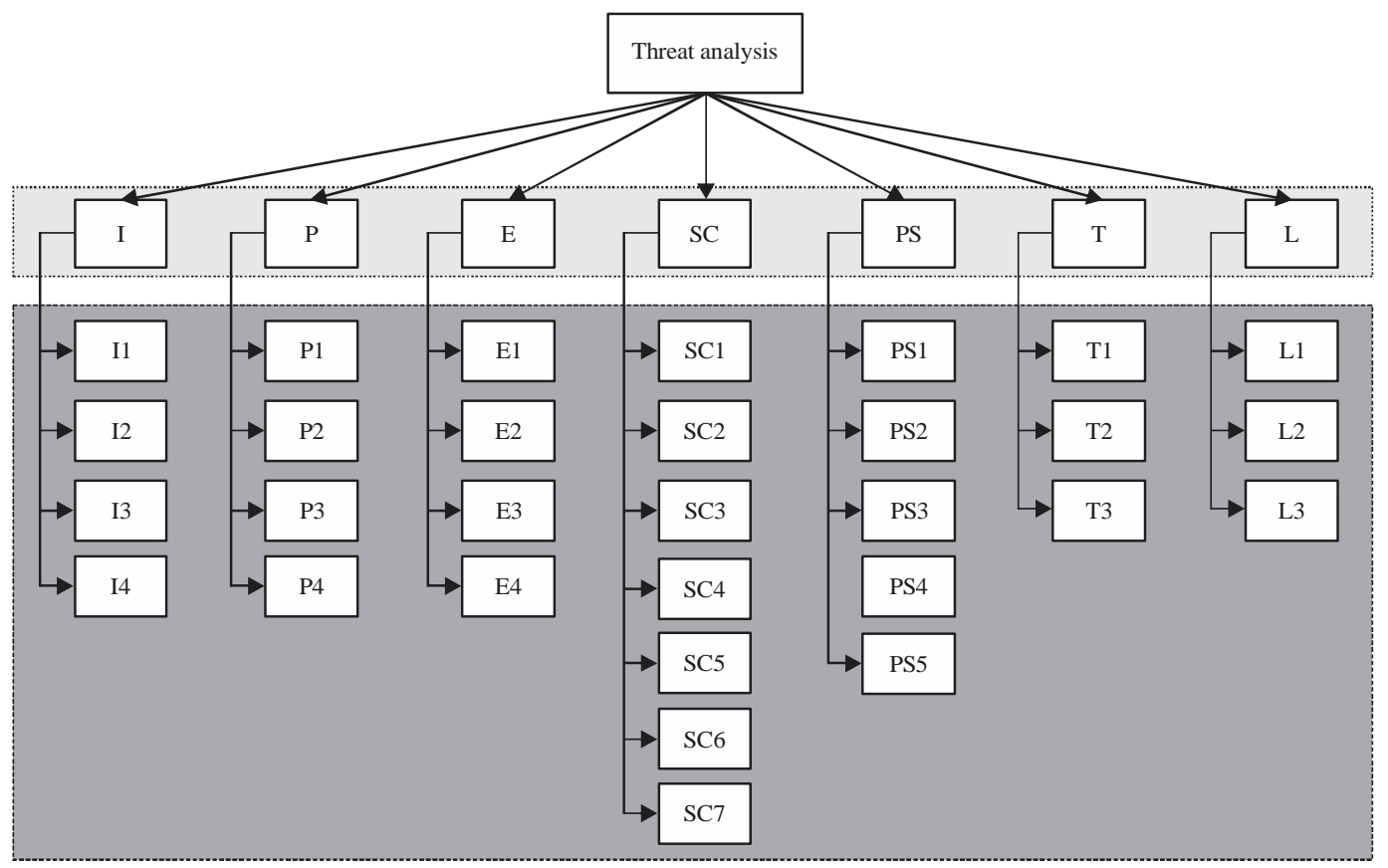

Fig. 5: Hierarchy model of threat analysis

Table 1: Criteria of threat analysis

\begin{tabular}{lll}
\hline Thread aspect & Code & Sub-criteria (code) \\
\hline Ideology & I & Individualism (I1), materialism (I2), radicalism (I3), anarchism (I4) \\
Politic & P & Trust to government (P1), separatism (P2), living environment (P3), democratization (P4) \\
Economy & E & Unemployment level (E1), infrastructure (E2), economic disparity (E3), low competitiveness (E4) \\
Social-Culture & SC & $\begin{array}{l}\text { Poverty (SC1), education level (SC2), SARA (Ethnic, Religion Groups, Race) conflict (SC3), social gap } \\
\text { (SC4), Foreign culture (SC5), human trafficking (SC6), corruption (SC7) }\end{array}$ \\
Public Safety & PS & Natural disaster (PS1), thuggery (PS2), terrorism (PS3), food and energy (PS4), narcotic crime (PS5) \\
Technology & T & Cyber threat (T1), technological lagging (T2), virus spread (T3) \\
Legality & L & Human right issues (L1), overlapping rules(L2), legal intervention (L3) \\
\hline
\end{tabular}


J. Eng. Applied Sci., 15 (2): 492-500, 2020

Table 2. Pairwise comparison of threat criteria

\begin{tabular}{lllllllll}
\hline Criteria & I & P & E & SC & PS & T & L & Weight \\
\hline I & 1 & 1 & 2 & 2 & $1 / 3$ & $1 / 2$ & $1 / 2$ & 0.115 \\
P & 1 & 1 & 1 & 2 & 2 & $1 / 2$ & 1 & 0.162 \\
E & $1 / 2$ & $1 / 2$ & 1 & $1 / 2$ & $1 / 3$ & 1 & $1 / 2$ & 0.074 \\
SC & $1 / 2$ & $1 / 2$ & 2 & 1 & $1 / 2$ & 2 & $1 / 3$ & 0.109 \\
PS & 3 & $1 / 2$ & 3 & 2 & 1 & 2 & 2 & 0.224 \\
T & 2 & 2 & 1 & $1 / 2$ & $1 / 2$ & 1 & $1 / 2$ & 0.133 \\
L & 2 & 1 & 2 & 3 & $1 / 2$ & 2 & 0.183 \\
CR & 0.08 & & & & & & & 1.000 \\
\hline
\end{tabular}

Table 3: Pairwise comparisons between ideology criteria

\begin{tabular}{llllll}
\hline Criteria & I1 & I2 & I3 & I4 & Weight \\
\hline I1 & 1 & $1 / 3$ & 2 & $1 / 3$ & 0.148 \\
I2 & 3 & 1 & 3 & 3 & 0.469 \\
I3 & $1 / 2$ & $1 / 3$ & 1 & $1 / 3$ & 0.104 \\
I4 & 3 & $1 / 3$ & 3 & 1 & 0.279 \\
CR $=$ & 0.080 & & & & 1.000 \\
\hline
\end{tabular}

Table 4: Pairwise comparisons between political criteria

\begin{tabular}{llllll}
\hline Criteria & P1 & P2 & P3 & P4 & Weight \\
\hline P1 & 1 & $1 / 3$ & $1 / 2$ & 2 & 0.174 \\
P2 & 3 & 1 & $1 / 2$ & 3 & 0.327 \\
P3 & 2 & 2 & 1 & 2 & 0.376 \\
P4 & $1 / 2$ & $1 / 3$ & $1 / 2$ & 1 & 0.123 \\
CR & 0.080 & & & & 1.000 \\
\hline
\end{tabular}

Table 5: Pairwise comparisons between Economic criteria

\begin{tabular}{llllll}
\hline Criteria & E1 & E2 & E3 & E4 & Weight \\
\hline E1 & 1 & 2 & $1 / 2$ & 2 & 0.287 \\
E2 & $1 / 2$ & 1 & 1 & 2 & 0.242 \\
E3 & 2 & 1 & 1 & 2 & 0.335 \\
E4 & $1 / 2$ & $1 / 2$ & $1 / 2$ & 1 & 0.136 \\
CR & 0.069 & & & & 1.000 \\
\hline
\end{tabular}

Table 6: Pairwise comparisons between socio-cultural criteria

\begin{tabular}{lllllllll}
\hline Criteria & SC1 & SC2 & SC3 & SC4 & SC5 & SC6 & SC7 & Weight \\
\hline SC1 & 1 & 1 & $1 / 3$ & $1 / 2$ & $1 / 3$ & $1 / 4$ & $1 / 2$ & 0.115 \\
SC2 & 1 & 1 & $1 / 3$ & $1 / 2$ & $1 / 2$ & $1 / 4$ & $1 / 3$ & 0.162 \\
SC3 & 2 & 2 & 1 & 1 & 2 & $1 / 3$ & $1 / 3$ & 0.074 \\
SC4 & 2 & 2 & 1 & 1 & $1 / 2$ & $1 / 3$ & 3 & 0.109 \\
SC5 & 3 & 2 & $1 / 2$ & 2 & 1 & $1 / 3$ & $1 / 3$ & 0.224 \\
SC6 & 4 & 4 & 3 & 3 & 3 & 1 & 5 & 0.133 \\
SC7 & 2 & 3 & 3 & $1 / 3$ & 3 & $1 / 5$ & 1 & 0.183 \\
CR & 0.096 & & & & & & & 1.000 \\
\hline
\end{tabular}

Table 7: Pairwise comparisons between public safety criteria

\begin{tabular}{lllllll}
\hline Criteria & PS1 & PS2 & PS3 & PS4 & PS5 & Weight \\
\hline PS1 & 1 & 3 & 2 & 2 & 3 & 0.371 \\
PS2 & $1 / 3$ & 1 & 1 & 2 & 3 & 0.205 \\
PS3 & $1 / 2$ & $1 / 2$ & 1 & 3 & 2 & 0.195 \\
PS4 & $1 / 2$ & $1 / 2$ & $1 / 3$ & 1 & $1 / 3$ & 0.095 \\
PS5 & $1 / 3$ & $1 / 3$ & $1 / 2$ & 3 & 1 & 0.134 \\
CR & 0.069 & & & & & 1.000 \\
\hline
\end{tabular}

Table 8: Pairwise comparisons between technology criteria

\begin{tabular}{llllc}
\hline Criteria & T1 & T2 & T3 & Weight \\
\hline T1 & 1 & $1 / 3$ & $1 / 3$ & 0.142 \\
T2 & 3 & 1 & $1 / 2$ & 0.334 \\
T3 & 3 & 2 & 1 & 0.525 \\
CR & 0.046 & & & 1.000 \\
\hline
\end{tabular}

Based on Table 3, in the criteria of the ideological aspect (I) it is known that the sub-criteria of Individualism (I1) has a weight of 0.148 , Materialism (I2) sub-criteria has a weight of 0.469 , radicalism (I3) sub-criteria has a weigh of 0.104 , anarchism sub-criteria (I4) has a weight of 0.279 .

Based on the Table 4, in the criteria of the Political aspect $(\mathrm{P})$ it is known that the sub-criteria of trust in government (P1) has a weight of 0.174 , the separatism sub-criteria (P2) has a weight of 0.327 , sub environmental criteria (P3) has a weight of 0.376 , the democratization sub-criteria (P4) has a weight of 0.123 .

Based on Table 5, in the Economic aspect criteria (E) it is known that the unemployment sub-criteria (E1) has a weight of 0.287 , infrastructural sub-criteria (E2) has a weight of 0.242, the Economic gap sub-criteria (E3) has a weight of 0.335 , the low competitiveness sub-criteria (E4) has a weight of 0.136.

Based on Table 6, in the Socio-Cultural aspect criteria (SC), it is known that the poverty Sub-Criteria (SC1) has a weight of 0.115 , the education level Sub-Criteria (SC2) has a weight of 0.162 , the sub-criteria for SARA (Ethnic, Religion Groups, Race) conflict (SC3) has a weight of 0.074 , the social gap sub-criteria (SC4) has a weight of 0.109 , foreign culture sub-criteria (SC5) has a weight of 0.224 , human trafficking sub-criteria (SC6) has a weight of 0.133, corruption Sub-Criteria (SC7) has a weight of 0.183 .

Based on Table 7, in the criteria for the aspect of Public Safety (PS) it is known that the natural disaster sub-criteria (PS1) has a weight of 0.371 , thuggery sub-criteria (PS2) has a weight of 0.205 , terrorism sub-criteria (PS3) has a weight of 0.195 , food and energy sub-criteria (PS4) has a weight of 0095, narcotics crime sub-criteria (PS5) has a weight of 0.134 .

Based on Table 8, in the criteria of the Technology aspect $(\mathrm{T})$, it is known that the cyber threat sub-criteria (T1) has a weight of 0.142 , technology lagging criteria (T2) has a weight of 0.334 , virus spread criteria (T3) has a weight of 0.525 .

Based on Table 9, in the criteria for the Legality aspect (L), it is known that the human rights sub-criteria issue (L1) has a weight of 0.27 , overlapping rule (L2) sub-criteria have a weight of 0.54 , Legal intervention (L3) sub-criteria have a weight of 0.19 . The next step is to provide an analysis of non-military threats by determining the overall criteria with the corresponding scale factor. 
Table 9: Pairwise comparisons between legality criteria

\begin{tabular}{lllll}
\hline Criteria & L1 & L2 & L3 & Weight \\
\hline L1 & 1 & $1 / 3$ & 2 & 0.27 \\
L2 & 3 & 1 & 2 & 0.54 \\
L3 & $1 / 2$ & $1 / 2$ & 1 & 0.19 \\
CR & 0.08 & & & 1.00 \\
\hline
\end{tabular}

Table 10: Overall priority of threat analysis for non-military aspect

\begin{tabular}{|c|c|c|c|c|}
\hline Aspect & Sub criteria & Local weight & Total weight & Priority \\
\hline Ideology & Individualism (I1) & 0.148 & 0.017 & 23 \\
\hline \multirow[t]{3}{*}{0.115} & Materialism (I2) & 0.469 & 0.054 & 5 \\
\hline & Radicalism (I3) & 0.104 & 0.012 & 27 \\
\hline & Anarchism (I4) & 0.279 & 0.032 & 13 \\
\hline Politics & Trust in government (P1) & 0.174 & 0.028 & 15 \\
\hline \multirow[t]{3}{*}{0.162} & Separatism (P2) & 0.327 & 0.053 & 6 \\
\hline & Living environment (P3) & 0.376 & 0.061 & 4 \\
\hline & Democratization(P4) & 0.123 & 0.020 & 19 \\
\hline Economy & Unemployment level (E1) & 0.287 & 0.021 & 18 \\
\hline \multirow[t]{3}{*}{0.074} & Infrastructure (E2) & 0.242 & 0.018 & 22 \\
\hline & Economic disparity (E3) & 0.335 & 0.025 & 16 \\
\hline & Low competitiveness (E4) & 0.136 & 0.010 & 28 \\
\hline Social-culture & Poverty(SC1) & 0.057 & 0.006 & 30 \\
\hline \multirow{6}{*}{0.109} & Education level (SC2) & 0.057 & 0.006 & 29 \\
\hline & SARA (Ethnic. Religion Groups. Race) conflict (SC3) & 0.121 & 0.013 & 26 \\
\hline & Economic disparity (SC4) & 0.136 & 0.015 & 24 \\
\hline & Foreign Culture (SC5) & 0.126 & 0.014 & 25 \\
\hline & Human trafficking (SC6) & 0.337 & 0.037 & 11 \\
\hline & Corruption (SC7) & 0.166 & 0.018 & 21 \\
\hline Public safety & Natural disaster (PS1) & 0.371 & 0.083 & 2 \\
\hline \multirow[t]{4}{*}{0.224} & Unemployment (PS2) & 0.205 & 0.046 & 8 \\
\hline & Terrorism (PS3) & 0.195 & 0.044 & 10 \\
\hline & Food and Energy (PS4) & 0.095 & 0.021 & 17 \\
\hline & Narcotics crime (PS5) & 0.134 & 0.030 & 14 \\
\hline Technology & Cyber threat (T1) & 0.142 & 0.019 & 20 \\
\hline \multirow[t]{2}{*}{0.133} & Technological lagging (T2) & 0.334 & 0.044 & 9 \\
\hline & Virus spread (T3) & 0.525 & 0.070 & 3 \\
\hline Legality & Human rights Issue (L1) & 0.268 & 0.049 & 7 \\
\hline \multirow[t]{2}{*}{0.183} & Overlapping rules (L2) & 0.537 & 0.099 & 1 \\
\hline & Legal Intervention (L3) & 0.195 & 0.036 & 12 \\
\hline
\end{tabular}

Based on the weighting results (Table 10) by using AHP method at level I, it was found that the highest threat aspect was the general safety aspect with a weight of 0.224 . The aspect of public safety consists of the threat of natural disasters, threats of thuggery, threats of terrorism, threats of food and energy and narcotics crimes. While the lowest threat aspect is the economic aspect with a weight of 0.074 . The economic aspect consists of the threat of unemployment, low infrastructure, the threat of economic disparity and the threat of low competitiveness.

At level II, the highest threat is that there are overlapping rules from the regional government that make some management processes complicated and can give inconvenience to the residents and investors. Overlapping sub-criteria for the rules have a weight of 0.099. While the lowest threat is poverty with a weight of 0.006 . Poverty is indeed a problem for some regions in Indonesia, especially in remote areas, while in the Bandung Municipality as a buffer zone of the capital city Jakarta has several programs related to poverty alleviation.
The security and defense stability of a region is the most important aspect, without the security and defense stability it will not be called a state. Regional development is an effort to realize the sovereignty rights as a country. Therefore, the scope of regional development is related to the problem of resolving the regional stability. Improving the local community welfare is also very important in terms of the resilience nation aspect.

The defense aspect is not only a simple aspect of defense involving conventional threats such as military invasions of other countries, but also more complex, namely non-military aspects consisting of ideology, politics, economics, socio-culture, public safety, technology and legality. If the non-military threat is not resolved, the non-military forces will enter and influence the population and damage for the life of a nation. Furthermore, it has an impact on the weakness of the national defense and security system. 


\section{CONCLUSION}

The development of strategic environmental issues has an impact on state sovereignty in the form of sovereignty threats. At present, the threat is no longer a military threat but also a non-military threat in the form of ideological, political, socio-cultural, economic, public safety, technology and legality of law threats. The existence of non-military threats certainly has an impact on the obstruction of the nation's national ideals in general and the impact on regional government including Bandung Municipality.

Based on the results of the study, the Bandung Municipality has 7 dimensions of non-military threats which include the threat of ideology with a weight of 0.115 consisting of 4 sub-criteria namely individualism, materialism, radicalism, anarchism. Political threats have a weight of 0.162 consisting of sub-criteria of trust in government, separatism, environment, democratization. Economic threats have a weight of 0.074 consisting of sub-threats to unemployment, infrastructure, economic disparity and low competitiveness. The threats of socio-culture have a weight of 0.109 which consists of sub-threats of poverty, education level, SARA (Ethnic, Religion Groups, Race) conflict, social gap, foreign culture, human trafficking and corruption. Public safety threats have a weight of 0.224 consisting of sub-threats of natural disasters, thuggery, terrorism, food and energy and narcotics crime. The technology threats have a weight of 0.133 which consists of cyber threats, technological lagging and the spread of viruses. The threats of legality have a weight of 0.183 consisting of human rights issues, overlapping rules, legal intervention.

At level I, the highest threat aspect is the public safety aspect with a weight of 0.224 . While the lowest threat aspect is the economic aspect with a weight of 0.074. Otherwise, at level II, the highest one is the overlapping of rules from the regional government with a weight of 0.099 . While the lowest threat is poverty with a weight of 0.006 .

\section{ACKNOWLEDGEMENT}

This study supported by Brawijaya University. We also thanks to our colleges Dr. I Nengah Putra from Indonesian Defense University who provided insight and expertise that greatly the research.

\section{REFERENCES}

Aldianto, L., A.A. Budi, G. Anggadwita, S. Novani and C. Wirawan, 2019. City branding vs. cultural branding: Towards a theoritical for developing bandung identity. Kinerja, 23: 42-53.
Anis, A. and R. Islam, 2015. The application of analytic hierarchy process in higher-learning institutions: A literature review. J. Int. Bus. Entrepreneurship Dev., 8: 166-182.

Chaerul, M., M. Tanaka and A.V. Shekdar, 2007. Municipal solid waste management in Indonesia: Status and the strategic actions. J. Fac. Environ. Sci. Technol., 12: 41-49.

Chien, H.J. and S. Barthorpe, 2013. Using analytic hierarchy process to analyse the critical success factors for performance management of the Taiwanese Veterans Home. Int. J. Applied Sci. Technol., 3: 48-63.

Chua, S.J.L., A.S. Ali and A.B. Alias, 2015. Implementation of Analytic Hierarchy Process (AHP) decision ma king framework for building maintenance procurement selection: Case study of Malaysian public universities. Operat. Reliab., 17: 7-18.

Dlbokic, M., D. Nikolic, P. Dordevic, M. Panic and Z. Zivkovic, 2017. SWOT-AHP model for prioritization of strategies for development of viticulture in Jablanica district-Serbia. Strategic Manage., 22: 44-52.

Gosavi, V.V. and K.H. Inamdar, 2014. Defect reduction in fabricated components using root-cause analysis. Int. J. Eng. Res. Technol., 3: 2026-2032.

Grozdanoska, N., 2014. National defence and security. Eur. Sci. J., 1: 305-311.

Ho, F., S.H. Abdul-Rashid and R.A.R. Ghazilla, 2016. Analytic hierarchy process-based analysis to determine the barriers to implementing a material efficiency strategy: Electrical and electronics' companies in the Malaysian context. Sustainability, 8: $1-16$.

Hou, C.I., C. Huang, H. Tsai and C.Y. Lo, 2015. Research on decision making regarding high-business-strategy cafe menu selection. Intl. J. Comput. Sci. Inf. Technol., 7: 89-97.

Indrayani, E., 2018. Implementation of Smart City: Cooperation development among municipality, private sectors and communities (the study of municipality of Bandung). Int. J. Applied Bus. Econ. Res., 16: 85-92.

Jones, M., C. Meijen, P.J. McCarthy and D. Sheffield, 2009. A theory of challenge and threat states in athletes. Int. Rev. Sport. Exerc. Psychol., 2: 161-180.

Jouini, M., L.B.A. Rabai and R. Khedri, 2015. A multidimensional approach towards a quantitative assessment of security threats. Procedia Comp. Sci., 52: 507-514.

Kalutara, P., G. Zhang, S. Setunge and R. Wakefield, 2018. Prioritising sustainability factors for Australian community buildings management using Analytical Hierarchy Process (AHP). Int. J. Strategic Property Manage., 22: 37-50. 
Karakayaci, Z., 2015. Using of analytic hierarchy process on evaluating the affecting factors in the value of farmlands. Bulg. J. Agric. Sci., 21: 719-724.

Maharma, A.H. and Y. Saleh, 2014. Developing a business performance management model for paltel group-palestine. Proceedings of the International Symposium on the Analytic Hierarchy Process (ISAHP2014), June 29-July 2, 2014, Washington, DC, USA., pp: 1-18.

Mastapeter, C.W., 2008. The instruments of national power: Achieving the strategic advantage in a changing world. Master's Thesis, Defense Technical Information Center Government Department, Naval Postgraduate School, Naval Postgraduate School Monterey, California, USA.

Menon, N., K.K. Kamath and A.R. Shabaraya, 2016. Conducting root cause analysis and its implementation: A perspective. Manipal J. Pharm. Sci., 2: 21-25.

Miftah, A.Z., S. Sasmono, A. Sunarwibowo, A.F. Khairani and K. Moroga, 2019. Preliminary study on Bandung sustainable urban mobility policy: The contribution of public transportation on emission. IOP Conf. Series: Earth Environ. Sci., Vol. 248, No. 1. 10.1088/1755-1315/248/1/012032.

Mutmainah, U. Marfuah and A.T. Panudju, 2017. Employee performance appraisal model using human resources scorecard and Analytical Hierarchy Process (AHP). Int J. Sci. Technol. Res., 6: 81-84.

Ramkumar, A. and S. Gopalakrishnan, 2014. Root cause analysis of issues in construction industry. Intl. J. Innovative Res. Sci. Eng. Technol., 3: 1-10.

Saaty, T.L. and L.G. Vargas, 2006. Decision Making with the Analytic Network Process. Springer, New York, USA., ISBN:978-1-4614-7278-0,.
Saaty, T.L., 2003. Decision-making with the AHP: Why is the principal eigenvector necessary. Eur. J. Operat. Res., 145: 85-91.

Septiawan, D.B. and R. Bekti, 2016. Analysis of project construction delay using fishbone diagram at PT. Rekayasa Industri. J. Bus. Manage., 5: 634-650.

Setiarso, B., O.S. Suharyo and A.K. Susilo, 2018. Determination of landing beach location for amphibious operations on the west Papua Sea with Analytic Hierarchy Process (AHP): Case study on sorong regency. J. Defense Resour. Manage., 9: 21-33.

Singh, D.K., A. Kumar and M.K. Dash, 2016. Using analytic hierarchy process to develop hierarchy structural model of consumer decision making in digital market. Asian Acad. Manage. J., 21: 111-136.

The Ministry of Defence, 2015. Indonesian Defence White Paper. Ministry of Defence of the Republic of Indonesia, Jakarta, ISBN: 978-979-8878-04-6, Pages: 150.

Van Der Putten, F.P., M. Meijnders and J. Rood, 2015. Deterrence as a security concept against non-traditional threats. Netherlands Institute of International Relations Clingendael, The Hague, Netherlands.

Wang, M.T., 2015. Use of a combination of AHP and ISM for making an innovative rescue caring design in landslide area. Math. Prob. Eng., Vol. 2015. 10.1155/2015/401736.

Zhou, J. and S. Li, 2015. Distance based root cause analysis and change impact analysis of performance regressions. Math. Prob. Eng., Vol. 2015. 10.1155/2015/690829. 